\title{
Evaluation of speed of sound aberration and correction for ultrasound guided radiation therapy
}

Citation for published version (APA):

Fontanarosa, D. (2014). Evaluation of speed of sound aberration and correction for ultrasound guided radiation therapy. [Doctoral Thesis, Maastricht University]. Datawyse / Universitaire Pers Maastricht. https://doi.org/10.26481/dis.20140326df

Document status and date:

Published: 01/01/2014

DOI:

$10.26481 /$ dis.20140326df

Document Version:

Publisher's PDF, also known as Version of record

\section{Please check the document version of this publication:}

- A submitted manuscript is the version of the article upon submission and before peer-review. There can be important differences between the submitted version and the official published version of record.

People interested in the research are advised to contact the author for the final version of the publication, or visit the DOI to the publisher's website.

- The final author version and the galley proof are versions of the publication after peer review.

- The final published version features the final layout of the paper including the volume, issue and page numbers.

Link to publication

\footnotetext{
General rights rights.

- You may freely distribute the URL identifying the publication in the public portal. please follow below link for the End User Agreement:

www.umlib.nl/taverne-license

Take down policy

If you believe that this document breaches copyright please contact us at:

repository@maastrichtuniversity.nl

providing details and we will investigate your claim.
}

Copyright and moral rights for the publications made accessible in the public portal are retained by the authors and/or other copyright owners and it is a condition of accessing publications that users recognise and abide by the legal requirements associated with these

- Users may download and print one copy of any publication from the public portal for the purpose of private study or research.

- You may not further distribute the material or use it for any profit-making activity or commercial gain

If the publication is distributed under the terms of Article $25 \mathrm{fa}$ of the Dutch Copyright Act, indicated by the "Taverne" license above, 
Summary 

The aim of radiotherapy (RT) is to deliver a precisely controlled radiation dose to the target, while sparing the normal tissue and possible nearby organs at risk. To improve accuracy in delivery, ultrasound guidance (USgRT) can help patient positioning before each treatment session. Quantitative use of ultrasound (US) has historically been limited by aberrations, among which speed of sound (SOS) aberration is one of the most difficult to correct for. In this work we found a correction strategy which makes use of the coregistered computerized tomography (CT) scan as source for physical density information. This is then transformed into SOS map of the patient and used for the cumulative correction. A general introduction is given in Chapter 1 on the background and importance of US applications in RT. A more detailed description of US technology is presented in Chapter 2. This is part of an invited review for Physics in Medicine and Biology. The aim is to make the reader more familiar with the concepts used in the rest of the thesis and to provide a convenient framing in the field of RT. With Chapter 3 the idea based on the observation that in RT a CT scan is always available, which can be used as source for physical density, is introduced. The MATLAB algorithm created for the correction is described in detail. Validation on phantoms was performed and a first simplified application on a prostate and a breast cases showed. In Chapter 4 a systematic study of the SOS aberration correction effect on different clinical scenarios is reported. Five prostate, five breast and five liver cancer cases were examined. On each of them, the correction was applied and the magnitudes of the shifts produced by the algorithm were considered indications of the impact of the aberration. The results show that for liver the aberration is unpredictable for the effects on both structures depth and shape. So, in our dataset, a correction was always necessary, since errors up to more than $7 \mathrm{~mm}$ in positions of the regions of interest (ROI) were measured. Also for the prostates, an average error of about $3 \mathrm{~mm}$ in the position of the centroids was sufficient to suggest a correction for SOS aberration. The magnitude and direction of these shifts were in good agreement with the discrepancies reported in literature, which made us hypothesize that SOS aberration might be an explanation for a large part of them. For breasts, small shifts were measured, typically around $1 \mathrm{~mm}$. We did not exclude that the limited dataset with possibly small breasts might have biased these results. But from our experience, it does not seem that for these organs a correction is strictly required. In Chapter $\mathbf{5}$ the sensitivity of the procedure to workflows and changes in the patients was examined. All the possible combinations of the clinical workflows and changes that can occur in the patient or to the scanning protocol were addressed. We extensively tested the robustness with extreme parameter variations in phantoms, even slightly outside clinical conditions. At the end, it was possible to claim that if no major changes happen, where by major we mean changes that would require re-planning of the treatment, the algorithm produces correct results. In particular, it produces better results than each of the workflows 


\section{SUMMARY}

considered, and always with discrepancies below the clinically detectable threshold. Once the algorithm was validated on phantoms, tested on patients and proven robust, we extended in Chapter 6 its range of application. From the initial parallelepipedal volumes produced by linear probes, we re-coded it in $\mathrm{C}++$ to a more general case of a generic 3D US volume produced by a curvilinear probe, which includes the previous shape but allows also any volume with non-parallel paired sides. The new algorithm was validated on a pelvic phantom. Then it was applied to 15 prostate cancer patients. The results confirmed the conclusions of Chapter 4, showing the same direction and average magnitude for the SOS aberration. Chapter $\mathbf{7}$ is based on the observation that, as reported in literature, CT and US visualize the tissues differently. In particular, to some extent they provide complementary information, because US can image soft tissues with high contrast and resolution, typically on limited spatial volumes. CT instead produces larger images with well-defined bony structures, invisible to US. The segmentation algorithm presented makes for the first time a simultaneous use of the information from both modalities; for the first time it is natively in 3D space, and again for the first time it is completely automatic. It is intelligent, meaning that it can be trained on a specific dataset representing the characteristics of a patients' population. We asked an experienced physician to contour the prostates on the fusion of 16 coregistered CT and US scans. The algorithm was able to reproduce independently the contours to an excellent degree. In Chapter 8 the results obtained are critically reviewed in view of possible future developments. 